\title{
Heterogeneous links between urban form and mobility: A comparison of São Paulo, Istanbul and Mumbai
}

\author{
Jens Kandt \\ University College London \\ j.kandt@ucl.ac.uk
}

\begin{abstract}
This paper presents determinants of travel demand in three important cities in emerging economies: São Paulo, Istanbul and Mumbai. By comparison, similarities and differences of travel demand among the cities are identified and discussed with regard to their geographical, institutional and spatio-physical conditions. Special attention is paid to the hitherto understudied impact of the built environment on travel in emerging economy cities. Drawing on identical household surveys carried out in each city, the study reveals that gender, social status, car ownership and geographical location are consistently associated with mode choice. Yet, the relative importance of those characteristics differs in each city in line with their distinct socio-cultural realities. Trip duration appears to be more affected by built-environment characteristics, once mode choice is taken into account. But, again, potential influences of the built environment operate in different ways in São Paulo, Istanbul and Mumbai. In particular, there appears to be a closer relationship between transport and land-use in Mumbai. The variation-finding, comparative design reveals plural associations of life situation, the built environment and travel, and thus evinces specific interactions that require contextual policy attention to achieve sustainable and inclusive urban mobility.
\end{abstract}

\section{Article history:}

Received: December 14, 2017

Received in revised form:

May 13, 2018

Accepted: July 15, 2018

Available online: October 12, 2018

Data availability: jtlu.org/index. $\mathrm{php/jtlu/article/view/1359}$

Copyright 2018 Jens Kandt

http://dx.doi.org/10.5198/jtlu.2018.1359

ISSN: 1938-7849 | Licensed under the Creative Commons Attribution - Noncommercial License 4.0

The Journal of Transport and Land Use is the official journal of the World Society for Transport and Land Use (WSTLUR) and is published and sponsored by the University of Minnesota Center for Transportation Studies. 


\section{Introduction}

São Paulo, Istanbul and Mumbai are faced with many of the transport challenges identified in emerging economies - rapid motorization, congestion, infrastructure inadequacy, and declining travel speeds by all motorized modes, especially public transport (Bharadwaj, Ballare, Rohit, \& Chandel, 2017; Daily Sabah, 2014; MCGM, 2016; Rolnik \& Klinowitz, 2011; Tekeli, 2009). Even though non-motorized and collective modes of transport still dominate modal splits, nascent automobile use already severely strains the functioning of transport systems in such cities (Kenworthy, 2017).

The incompatibility of urban form and functions with even a low level of motorization have long led to a situation of "declining mobility" (Gakenheimer, 1999, p. 671) in many emerging economy cities. This trend disproportionately affects socially disadvantaged groups, whose situation is further exacerbated by lack of urban policy coordination, disproportionate investment into road infrastructure and consequent negative externalities (Ahmed, Lu, \& Ye, 2008; Lucas \& Porter, 2016; Rode, Kandt, $\&$ Baker, 2016; Salon \& Aligula, 2012). In these circumstances, the extensive use of collective or nonmotorized transport modes results from mode captivity likely to transition into private vehicle use as incomes rise (Kutzbach, 2009; Sudhakara Reddy \& Balachandra, 2012; Tarigan, Susilo, \& Joewono, 2014). Some researchers expect that mode captivity and restricted residential mobility amplifies the land use-travel relationship in emerging economies wherein the experience of transport disadvantage is largely determined by urban structure and accessibility (Cervero, 2013; Gakenheimer, 1999, 2011).

Indeed some of the few micro level studies on such cities suggest that denser and more mixed urban form is associated with reduced travel times and distance (Feng, Dijst, Prillwitz, \& Wissink, 2013; Manoj \& Verma, 2015, 2016; Salon \& Aligula, 2012; Shirgaokar, 2016), reduced vehicle ownership (Guerra, 2015; Huang, Cao, \& Cao, 2016; Zegras, 2010; Zhang, Wu, Li, Liu, \& Li, 2014), higher instance of non-motorized and collective transport modes (Ahmad \& de Oliveira, 2016; Larrañaga, Rizzi, Arellana, Strambi, \& Cybis, 2016; Salon \& Aligula, 2012; Pan, Shen, \& Zhang, 2009; Zhang, 2004; Lin \& Yang, 2009) and sometimes reduced trip generation (Ma, Mitchell, \& Heppenstall, 2014; Lin \& Yang 2009). Yet, the statistical influence of built environment characteristics on travel choices is at times modest and not always in the expected direction. Aspects of "life situation" (Scheiner, 2014), notably gender, age and social status, are frequently paramount (Adeel, Yeh, \& Zhang, 2016; Mahadevia, \& Advani, 2016; Manoj, Verma, \& Navyatha, 2015; Tran \& Schlyter 2010; de Vasconcellos, 2005).

As cities are confronted with an imperative to escape automobile dependence (Kenworthy, 2017), there is a need to better understand travel demand in these contexts and explore to which extent a stronger transport-land use relationship can indeed be ascertained and identified as an effective policy domain in delivering sustainable transport. Lack of reliable data on the built environment present a significant challenge in this endeavour, and only few studies successfully consider multiple aspects of the built environment including design (e.g., Larrañaga et al, 2016; Manoj \& Verma, 2016; Shirgaokar, 2016) in addition to wider geographical aspects such as distance to the CBD and the transit network. These characteristics belong to the famous group of "D variables" (Ewing \& Cervero, 2010; Cervero $\&$ Kockelman, 1997), a term to denote spatial and geographical determinants of travel as key planning parameters.

Recognizing this challenge, the objective of this paper is to contribute to the literature on urban form and travel demand in understudied contexts outside North America and Europe by comparing determinants of travel demand in São Paulo, Istanbul and Mumbai with a special focus on the role of land use in shaping travel demand. Through an identical research design implemented in each city, the paper identifies both similarities and differences in travel demand patterns and discusses their implication with respect to transport policy alternatives supporting sustainable and equitable mobility. 


\section{Transport and urban form in São Paulo, Istanbul and Mumbai}

\subsection{Transport policies and planning}

Transport authorities in São Paulo, Istanbul and Mumbai have recognized the negative impact of growing automobile use on the urban social and physical environment. The latest transport master plan of São Paulo explicitly promotes sustainable mobility and places a strong emphasis on the role of the metro network, bus corridors and cycling infrastructure (Prefeitura de São Paulo, 2015). The plan also highlights transit-oriented development as desirable land-use strategy. This orientation marks a considerable shift from past policies favoring automobility, wherein investment in public transport was largely left to the private sector (de Vasconcellos, 2005). Over the last decades, a rapid transit network composed of five metro lines, numerous corridors with exclusive bus lanes and suburban rail links has emerged. Nevertheless, São Paulo continues to suffer from increasing congestion, and regulatory responses showed limited success in attenuating the problem (Lucinda, Ledo, \& Meyer, 2013). In addition, high transit fares and poorer transit accessibility in peripheral and less affluent parts of the region compels poorer households to seek informal or private alternatives (Boisjoly, Moreno-Monroy, \& El-Geneidy, 2017; Kezič \& Durango-Cohen, 2012; de Vasconcellos, 2005).

Table 1: Demographic and transport characteristics of São Paulo, Istanbul and Mumbai.

\begin{tabular}{|c|c|c|c|c|}
\hline & & Sáo Paulo & Istanbul & Mumbai \\
\hline population $^{\mathrm{a}}$ & people & $20,605,102$ & $12,696,134$ & $20,748,395$ \\
\hline admin. city & people & $10,886,518$ & $\mathrm{n} / \mathrm{a}$ & $12,442,373$ \\
\hline outer region & people & $9,718,584$ & $\mathrm{n} / \mathrm{a}$ & $8,306,022$ \\
\hline population growth:' total & per cent & 2.73 & 3.00 & 0.94 \\
\hline admin. city & per cent & 0.85 & $\mathrm{n} / \mathrm{a}$ & 0.43 \\
\hline outer region & per cent & 5.54 & $\mathrm{n} / \mathrm{a}$ & 1.76 \\
\hline $\operatorname{area}^{\mathrm{c}}$ & $\mathrm{km}^{2}$ & 7,942 & 5,335 & 4,420 \\
\hline population density: ${ }^{c}$ gross & people $/ \mathrm{km}^{2}$ & 2,250 & 2,380 & 5,669 \\
\hline net & people $/ \mathrm{km}^{2}$ & 9,285 & 13,633 & 46,588 \\
\hline \multicolumn{5}{|l|}{ age $^{a}$} \\
\hline under 20 & per cent & 31.6 & 32.4 & 36.3 \\
\hline $20-39$ & per cent & 33.0 & 37.5 & 38.4 \\
\hline $40-59$ & per cent & 24.6 & 22.2 & 18.7 \\
\hline over 60 & per cent & 10.7 & 7.9 & 6.5 \\
\hline MRT network: ${ }^{c}$ length & $\mathrm{km}$ & 425 & 407 & 477 \\
\hline rail-based & $\mathrm{km}$ & 313 & 367 & 477 \\
\hline BRT corridors & $\mathrm{km}$ & 112 & 40 & 0 \\
\hline people within $1 \mathrm{~km}$ of network & per cent & 31.6 & 36.8 & 54.5 \\
\hline car ownership $^{d}$ & per $1,000 \mathrm{pp}$ & 368 & 139 & 36 \\
\hline
\end{tabular}

aSão Paulo 2007 (IGBE, 2010), Istanbul 2008 (TÜIK, 2010, Çakir et al., 2008), Mumbai 2001 (GoI, 2016, MMRDA, 2003). bannual compound growth rates, São Paulo 2000-2007, Istanbul 2000-2008, Mumbai 2001-2011 based on sources listed in a). ' geo-spatial analysis of shapefiles held at LSE Cities lsecities.net. 'São Paulo (Burdett, 2009); Istanbul (Gerçek, 2009); Mumbai (MMRDA, 2008)

Istanbul's transport policy responded to rapid motorization by investing heavily into the road network, and the city only began to develop a systematic high-capacity transit system after the millennium (Gerçek, 2009; Tekeli, 2009). Transport is governed by a single authority, the Istanbul Metropolitan 
Municipality (IMM), whose jurisdiction was extended from the metropolitan core to the entire province in 2004 (IMM, 2016). As in São Paulo, there has been a recent policy shift towards sustainable transportation made explicit in the 2023 Master Plan (IDA, 2014), which envisions a greater role of urban railways in providing regional connectivity, while also recognizing the importance of walking and cycling. The IMM has earmarked several billions of US-Dollars for the development of an extensive metro network within the next decade. A para transit network of private minibuses and shared taxis known as dolmuş has evolved organically with the city's increasingly disappearing informal settlements (also known as gecekondus) and are now integrated into the region's transport vision (IMM, 2016, p. 50).

In Mumbai, comparatively low car ownership has already caused an intense level of congestion, and yet motorization continues to increase rapidly (Bharadwaj et al., 2017). The transit system, mainly constituted by surface-level commuter railways and an extensive bus network, experiences demand that heavily exceeds capacity. More recently, Mumbai added a metro and a monorail line to its rail system. Non-motorized modes constitute still more than half of all trips, and it has long been lamented that transport policies have rarely aimed at improving walking or cycling conditions (Kenworthy, 2017; Tiwari, 2007). In addition, a variety of para transit services operate in Mumbai, notably the threewheeled auto-rickshaws and metered taxis in the central city. Current transport strategies set out in the 2016-2036 regional plan emphasize regional connectivity to be achieved by a heavily expanded metro network, an extended highway system, road widening schemes and the introduction of bus lane corridors (MMRDA, 2016; MCGM, 2016)

\subsection{Urban form}

The cities differ strongly in terms of their spatial organization. São Paulo, Istanbul and Mumbai can be arranged in an increasing spectrum of compaction and land-use intensity. GIS analysis reveals that, in Mumbai, average net population density is five times higher than in São Paulo and more than three times higher than in Istanbul (Table 1). Whereas almost all Paulistanos live in net residential density levels of lower than 30,000 people per $\mathrm{km} 2$, around 60 percent of Mumbaikars live in levels of 45,000 people per $\mathrm{km} 2$ and above (Figure 1). Istanbul occupies the middle of these two extremes. Viewed in relation to the mass rapid transport (MRT) network (metro, trains and bus rapid transit), compaction translates into different levels of proximity to transit: population census data shows that more than half of Mumbaikars, nearly one in five Istanbulites and one third of Paulistanos live within $1 \mathrm{~km}$ of the MRT network.

\section{Population distribution of}

\section{... net residential density}
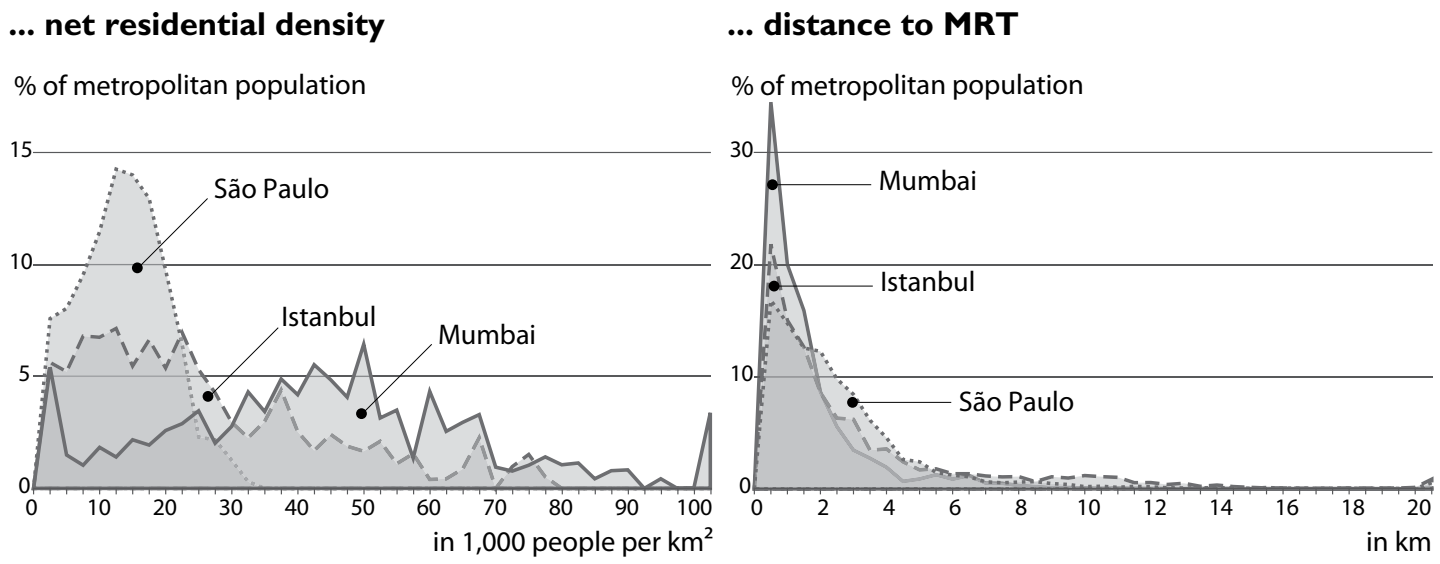

Figure 1: Urban form in São Paulo, Istanbul and Mumbai 
The urban footprints of the three metropolitan areas differ accordingly (Figures 2-4). São Paulo's population is dispersed over a large metropolitan region, while commercial activities are concentrated in the central area around Sé and Avenida Paulista and a few sub-centers in outer areas. Istanbul, famously divided by the Bosporus into two continents, has its commercial center in the denser European part, while the Asian part hosts less dense settlements of residences and retail. Mumbai's footprint and spatial extent highlights the extremely compact physical structure, which hosts several regional sub-centers and planned satellite towns.

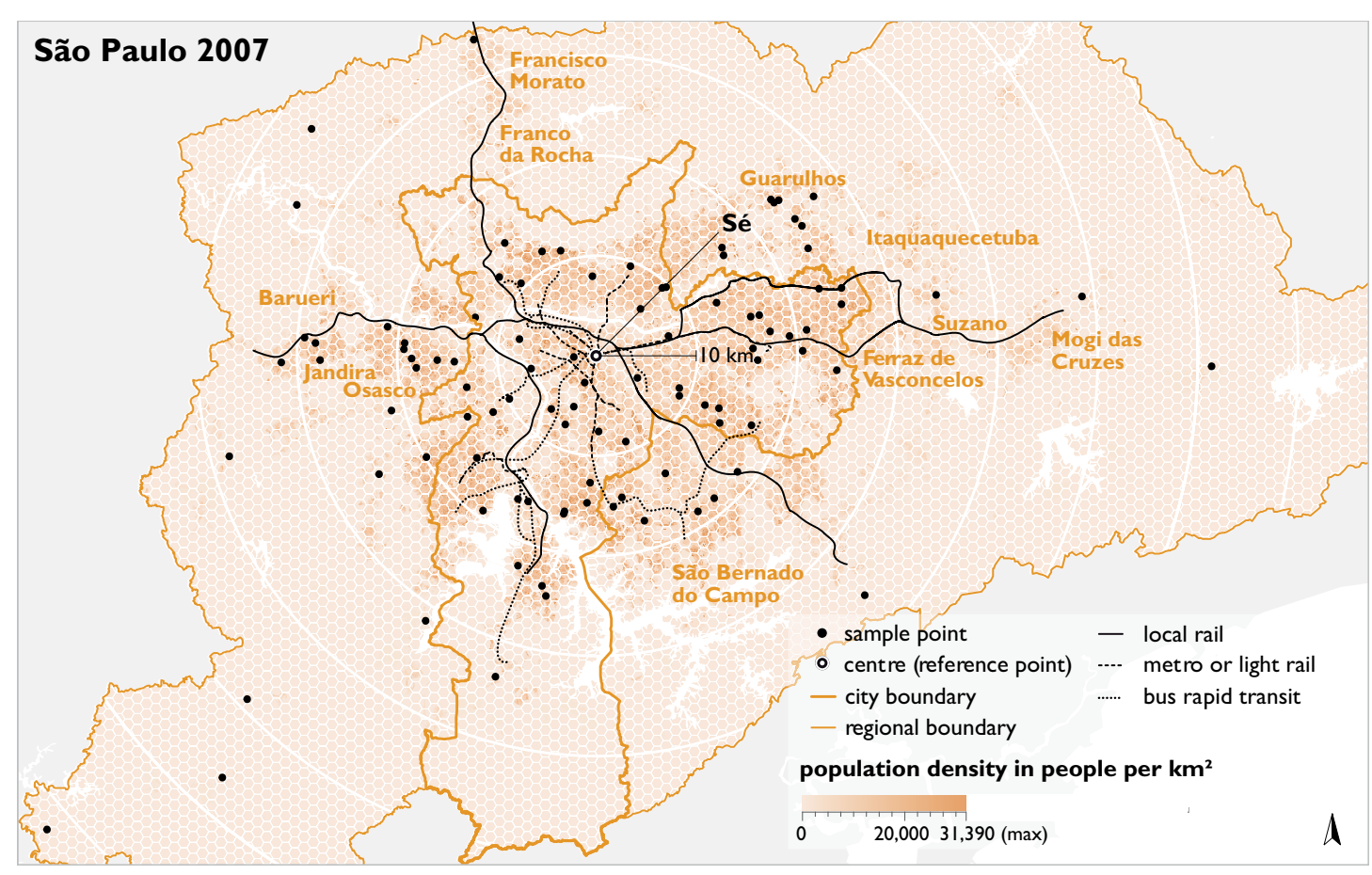

Figure 2: Sampling points and their geographical context in São Paulo 2008

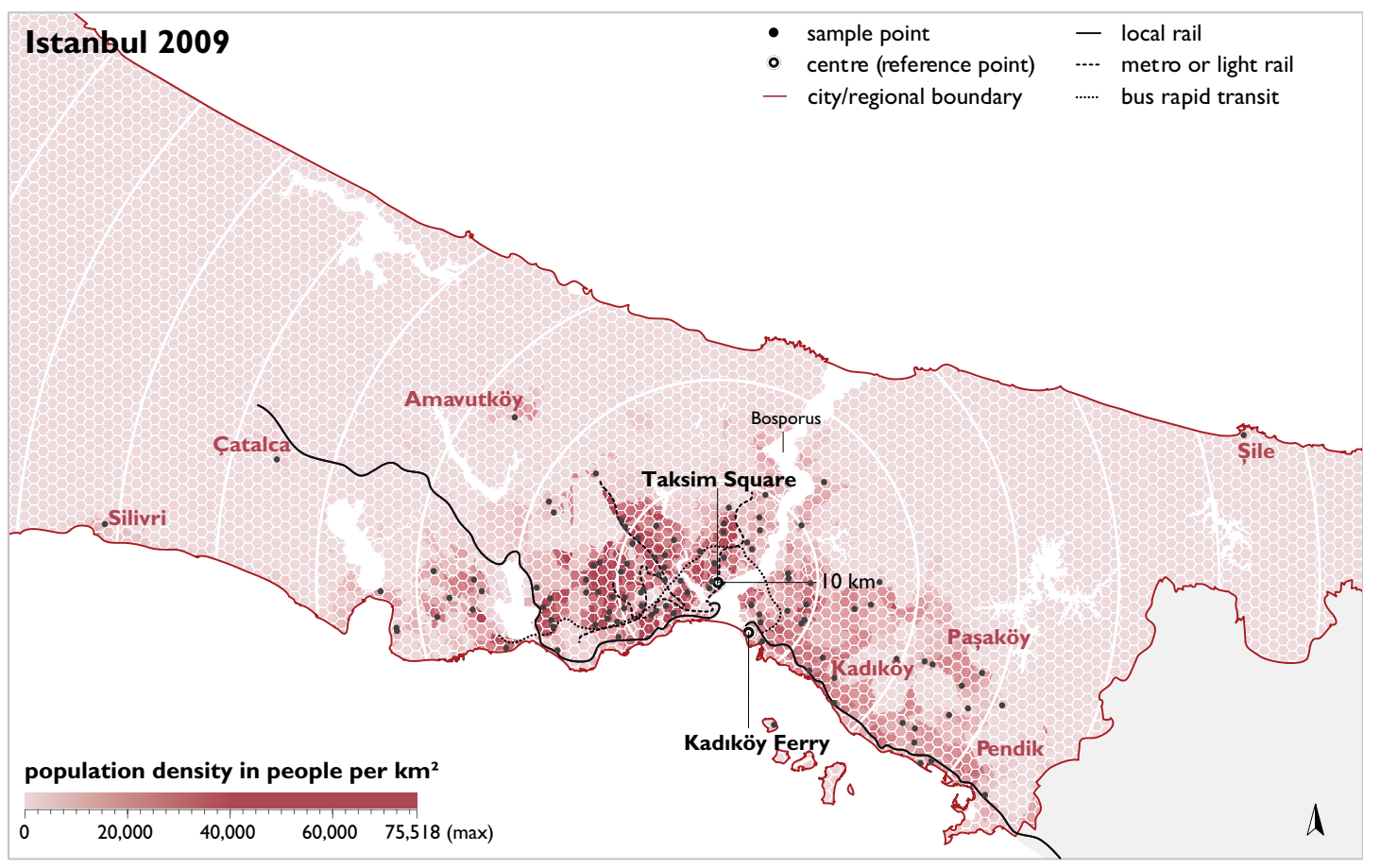

Figure 3: Sampling points and their geographical context in Istanbul 2009 


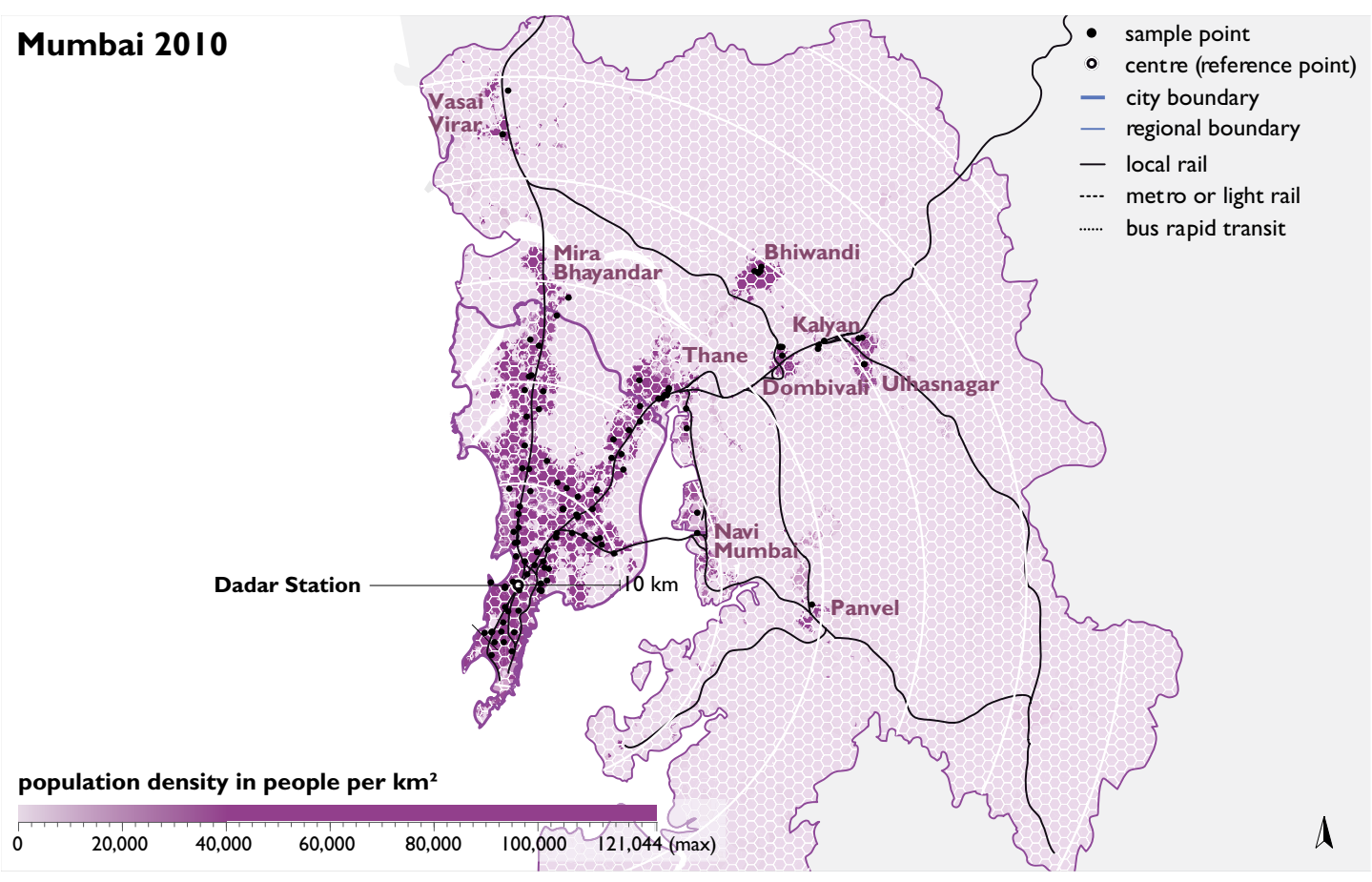

Figure 4: Sampling points and their geographical context in Mumbai 2010

In summary, while the three cities appear to experience very similar outcomes of declining mobility, congestion and excessive demand, they strongly differ in their spatial characteristics. In addition, they are each part of countries with very different socio-cultural histories and practices. This configuration offers a unique basis to unpack diverse processes involved in shaping travel demand within a comparative framework. Robinson (2011) envisions significant potential in comparative urban research to better account for the diverse urban experiences that exist outside established regions of knowledge production, i.e., the Global North. Her identified strategy of 'variation-finding' among 'most different cases' seems particularly applicable to the present study, in which similar urban outcomes occurring under very different conditions are co-analyzed and compared.

\section{$3 \quad$ Research design}

Three identical household surveys were conducted in São Paulo, Istanbul and Mumbai as part of the Urban Age program at the London School of Economics and Political Science (urbanage.lsecities.net). The program studies the interaction between social phenomena and physical characteristics in cities, and urban comparison is central to this endeavor. The surveys focus on the daily experience and quality of life and include one section on transport. The data analysis proceeded in two stages.

1. All respondents across all cities were pooled into one sample to identify the similarities in travel demand patterns. A dummy variable indicated city membership. Two kinds of models were specified: (a) Multinomial Logit models of mode choice and (b) Ordinary Least Square regression models of trip duration. The results are summarized in section 4 .

2. The same models of mode choice and trip duration were run as separate city-wise models to reveal differences in patterns between all cities. The differences uncovered in city-wise models were viewed against the common patterns, and in this way generic and city-specific tendencies were identified. The results are summarized and interpreted in section 5 . 


\subsection{Sampling, questionnaire and geo-spatial data}

A sample of 1,000 households each in São Paulo, Istanbul and Mumbai was surveyed in 2008, 2009 and 2010 respectively. Within each household, one respondent aged between 18 and 64 (last birthday method) was selected and interviewed about her or his main trip. The sample was age-censored in line with the objectives of the surveys, of which transport was one section among others. The impact of this limitation will be discussed below.

Since (northern) conventional RDD-based sampling strategies fail to reach a large part of the urban population in emerging economies, notably residents of informal settlements, an alternative design was adopted. One hundred survey points were sampled in each metropolitan region with the specification that 80 were to lie within the official city boundary and further 20 within the remainder of the official metropolitan region. This split was to ensure that a sufficiently diverse set of locations in terms of built environment characteristics was included. For Istanbul, the city boundary that existed up to 2004 was used to delimit the metropolitan core. At each survey point, interviewers would select ten households in a radius of one kilometer (see Figure 1). Weights based on age, sex and social status accounted for the geographical stratification and the respondent selection. Ipsos MORI was commissioned to carry out the field work in all three cities.

The survey collected data on the usual socio-demographic variables — gender, age, household size, socio-economic status, educational qualification and economic activity - as well as household vehicle ownership. Details of respondents' most regular trip were recorded. First, this included the trip purpose, which was assigned to seven classes (work, education, shopping, leisure, health services, personal interests and other). Second, respondents were asked to break their main trip down into segments and specify modes and travel times for each segment. Using this information, the dominant mode for each trip was defined as that which occupied the largest part of the full trip duration. Mechanized modes would supersede walking irrespective of travel time, however. The assumption herein was that if walking occurred as part of reaching a motorized mode, this segment would make a dependent element thereupon in the organization of the trip. Modes were then grouped into four categories: walking, public transport, para transit and car. Due to low numbers, respondents who rode bicycles or motorbikes were removed from the analysis.

"D variables" (Ewing \& Cervero, 2010) representing geographical and neighborhood context were derived from geo-spatial analysis of sample locations as well as directly from survey questions. The data source for geo-spatial analysis encompassed official shapefiles of transport networks, local censuses boundaries, urban land cover as well as mass transit stations and road networks taken from OpenStreetMap (OpenStreetMap, 2017). Indicators of location were defined as road network distance to the CBD and distance to the mass rapid transit network (MRT). Local rail, metros, light rail and bus routes with continuously segregated lines (São Paulo: SPTrans and EMTU corridors, Istanbul: Metrobüs route 34, Mumbai: none) considered as being part of the MRT system. To calculate the distances to the closest MRT station, the walking distance along the road network was calculated using the API of OpenTripPlanner (2018).

For the remaining $\mathrm{D}$ variables (density, diversity and design), which reflect local aspects of the built environment, one indicator for each was calculated. Net population density was derived from geo-spatial population estimates disaggregated to urban land cover and re-aggregated to one-square-kilometer hexagons. This process ensured that local density estimates are standardized and comparable within and between cities given diverse census zone designs.

Indicators of land-use diversity and neighborhood design were derived from the questionnaire. Land-use diversity is the average reported travel time to formal urban amenities in each neighborhood. Services included shopping areas/markets, parks, hospitals, public offices, theatres, museums and librar- 
ies. Distance to shopping areas was taken as the indicator of diversity, since other services had a high number of missing values. Principal Components Analysis on variables with fewer missing data confirmed that in each city, one component emerged in which travel time to shopping areas showed high loadings (Table S2, supplementary material).

Neighborhood design was captured through a combination of two variables: the type of housing (apartment block, house, condominium, all with/without the options of security/gate) and the neighborhood (slum, no slum, public housing estate), which was provided by the interviewers. Four items were generated from these questions: slums, apartment blocks, guarded properties and unguarded houses. Despite the contested nature of the term, slums emerged as the only workable term across the cities; it is used here in the broadest sense for informal, squatter and unplanned settlements. Full sample statistics and some technical notes on deriving ' $\mathrm{D}$ ' variables can be found in the supplementary material.

\subsection{Statistical models, variance partition and elasticities}

Mode choice and trip duration are available as indicators of individual, daily travel demand. In line with discrete choice modelling in transport studies (Ben-Akiva \& Lerman, 1985; Domencich \& McFadden, 1975), mode choice is estimated as multinomial logit between the alternatives walking, driving, para transit and the reference mode public transport. The model covariates include all respondent sociodemographics, mobility context variables, and neighborhood characteristics. Ordinary Least Square Regression models are used to estimate trip duration from the same covariates (simple models) and, separately, from additional dummies for mode choice (mode-adjusted models).

Every model is calibrated in 'backward-step' mode, whereby all covariates are included in the model in the first instance and iteratively removed or retained based on whether they significantly contribute to the variance. All models are fitted separately for work trips, non-work trips and all trips combined.

Since coefficients of Generalized Linear Models are not comparable across samples, they do not lend themselves to comparison of variable influence. In this situation, transport studies typically calculate model elasticities to establish the influence of a variable on travel choice. Elasticities, however, remain sensitive to measurement scale in a substantive sense: the relations between a unit change in, for example, gender, social class or population density are not quantifiable in a meaningful way. In addition, in multinomial logit models, elasticities are alternative-specific and thus not directly comparable.

Dominance Analysis presents an alternative way to establish the relative importance of variables given different measurement scales (Azen \& Budescu, 2003). A common approach to Dominance Analysis is the partitioning of explained variance into the contribution of each independent variable. This approach is particularly useful in the context of multinomial logit models, where variables are diversely associated with several alternatives (Luchman, 2014). In this way, both gradually different and contrasting tendencies across cities can be identified.

Nevertheless, individual point elasticities (following Domencich \& McFadden, 1975) were computed and reported for built environment variables in addition to the results from variance decomposition (following Luchman, 2014; Lindeman, Merenda, \& Gold,1980, p. 119). The statistical software used were standard packages of R (R Core Team, 2014) and additionally packages MASS (Venables \& Ripley, 2002), mlogit (Croissant, 2013), nnet (Venables \& Ripley, 2002) and relaimpo (Grömping, 2006). 


\section{Common determinants of travel demand in São Paulo, Istanbul and Mumbai}

\subsection{Overall travel demand patterns}

Descriptive results of selected travel choices from the survey reveal some general patterns shared across the cities. Walking is the most common mode in main trips in all cities, around half of the respondents walk in Istanbul and Mumbai and 37 percent in São Paulo (Table 2). Two in five use public transport in São Paulo and Mumbai, just one in five in Istanbul. Para transit is used by 12 percent in Mumbai and Istanbul, just four percent in São Paulo, where this comprises informal car pools. In São Paulo and Istanbul, the car is used by 16 and ten percent of respondents respectively; only a minority use the car in Mumbai.

Table 2: Relative frequencies of selected characteristics of survey respondents' main trips.

\begin{tabular}{|c|c|c|c|c|c|c|c|c|c|}
\hline & \multicolumn{3}{|c|}{ all trips } & \multicolumn{3}{|c|}{ work trips } & \multicolumn{3}{|c|}{ non-work trips } \\
\hline & SPO & IST & MBI & SPO & IST & MBI & SPO & IST & MBI \\
\hline $\mathbf{n}$ & 1,000 & 1,013 & 1,001 & 633 & 308 & 404 & 210 & 537 & 430 \\
\hline \multicolumn{10}{|l|}{ mode choice } \\
\hline walk & $37 \%$ & $53 \%$ & $45 \%$ & $32 \%$ & $31 \%$ & $29 \%$ & $51 \%$ & $70 \%$ & $60 \%$ \\
\hline public transport: bus & $30 \%$ & $12 \%$ & $13 \%$ & $30 \%$ & $19 \%$ & $11 \%$ & $25 \%$ & $8 \%$ & $11 \%$ \\
\hline public transport: MRT & $8 \%$ & $6 \%$ & $27 \%$ & $10 \%$ & $7 \%$ & $47 \%$ & $4 \%$ & $5 \%$ & $9 \%$ \\
\hline para transit & $4 \%$ & $12 \%$ & $12 \%$ & $4 \%$ & $18 \%$ & $10 \%$ & $3 \%$ & $10 \%$ & $14 \%$ \\
\hline car & $16 \%$ & $10 \%$ & $1 \%$ & $18 \%$ & $22 \%$ & $1 \%$ & $16 \%$ & $6 \%$ & $1 \%$ \\
\hline other & $4 \%$ & $7 \%$ & $3 \%$ & $5 \%$ & $2 \%$ & $2 \%$ & $0 \%$ & $0 \%$ & $5 \%$ \\
\hline \multicolumn{10}{|l|}{ trip duration } \\
\hline mean (mins) & 47.0 & 22.8 & 24.7 & 50.2 & 27.9 & 34.0 & 38.4 & 19.0 & 17.0 \\
\hline$\leq 10 \operatorname{mins}$ & $21 \%$ & $39 \%$ & $34 \%$ & $20 \%$ & $28 \%$ & $21 \%$ & $27 \%$ & $50 \%$ & $49 \%$ \\
\hline$>10$ to $30 \mathrm{mins}$ & $33 \%$ & $38 \%$ & $40 \%$ & $30 \%$ & $37 \%$ & $32 \%$ & $44 \%$ & $36 \%$ & $41 \%$ \\
\hline$>30$ to $60 \mathrm{mins}$ & $23 \%$ & $18 \%$ & $20 \%$ & $24 \%$ & $27 \%$ & $34 \%$ & $19 \%$ & $11 \%$ & $8 \%$ \\
\hline$>60$ mins & $23 \%$ & $5 \%$ & $6 \%$ & $25 \%$ & $8 \%$ & $13 \%$ & $10 \%$ & $3 \%$ & $1 \%$ \\
\hline \multicolumn{10}{|l|}{ trip purpose } \\
\hline workplace & $63 \%$ & $30 \%$ & $40 \%$ & $100 \%$ & $100 \%$ & $100 \%$ & - & - & - \\
\hline education & $3 \%$ & $10 \%$ & $10 \%$ & - & - & - & - & - & - \\
\hline shopping & $10 \%$ & $24 \%$ & $38 \%$ & - & - & - & $47 \%$ & $45 \%$ & $88 \%$ \\
\hline leisure & $3 \%$ & $14 \%$ & $3 \%$ & - & - & - & $15 \%$ & $27 \%$ & $8 \%$ \\
\hline health services & $5 \%$ & $3 \%$ & $5 \%$ & - & - & - & - & - & - \\
\hline personal interests & $8 \%$ & $15 \%$ & $2 \%$ & - & - & - & $38 \%$ & $28 \%$ & $4 \%$ \\
\hline other & $8 \%$ & $4 \%$ & $1 \%$ & - & - & - & - & - & - \\
\hline
\end{tabular}

SPO: São Paulo · IST: Istanbul · MBI: Mumbai. The figures refer to the declared main trip of respondents and not to all trips a respondent makes. 
In São Paulo, trips are nearly twice as long as in the other two cities for all purposes and modes; only one in five respondents travel less than ten minutes. Nearly one in four travels one hour or longer, compared to one in twenty in Istanbul and Mumbai. Viewed across all trips combined, both mode choice and trip duration reflect the different distribution of main trips. Nearly two thirds of Paulistanos have the workplace as their main destination, compared to 30 percent in Istanbul and 40 percent in Mumbai.

\subsection{Multinomial models of mode choice}

Mode choice is consistently associated with a range of social characteristics and the geographical context of trip makers (Table 3). In all trips — work and non-work - women are more likely to walk and use informal, para transit, whereas men tend to use the car in work trips and formal public transport in nonwork trips. Older trip makers are more likely to drive or walk than to use public transport. In non-work trips, they tend to use para transit instead of the car. 
Table 3: Coefficients and standard errors from multinomial logit models of mode choice in the pooled sample.

\begin{tabular}{|c|c|c|c|c|c|c|c|c|c|}
\hline & \multicolumn{3}{|l|}{ all trips } & \multicolumn{3}{|l|}{ work trips } & \multicolumn{3}{|c|}{ non-work trips } \\
\hline & $\mathrm{car}$ & paratransit & walk & car & paratransit & walk & $\mathrm{car}$ & paratransit & walk \\
\hline \multirow[t]{2}{*}{ (intercept) } & $-5.147^{* * *}$ & $-4.519^{* * *}$ & -.534 & -1.666 & -1.970 & -.193 & $-7.432^{* *}$ & $-6.039^{* * *}$ & -.480 \\
\hline & $(1.359)$ & $(1.102)$ & $(.672)$ & (1.654) & (1.517) & $(.946)$ & $(2.701)$ & $(1.775)$ & $(1.151)$ \\
\hline \multirow[t]{2}{*}{ gender: female } & -.264 & $.543^{* * *}$ & $.557^{* * *}$ & $-.582^{*}$ & .415 & $.321^{*}$ & -.383 & .355 & $.454^{*}$ \\
\hline & $(.180)$ & $(.159)$ & $(.098)$ & $(.252)$ & $(.256)$ & $(.159)$ & $(.347)$ & $(.269)$ & $(.177)$ \\
\hline \multirow[t]{2}{*}{ age } & $.030^{* * *}$ & $.010^{\wedge}$ & $.012^{* * *}$ & $.024^{*}$ & -.009 & .009 & .008 & $.022^{*}$ & $.017^{* *}$ \\
\hline & $(.006)$ & $(.006)$ & $(.004)$ & $(.010)$ & $(.010)$ & $(.006)$ & $(.012)$ & $(.010)$ & $(.006)$ \\
\hline \multicolumn{10}{|l|}{ household size } \\
\hline \multirow[t]{2}{*}{ social status } & $.353^{*}$ & .058 & $-.106^{\wedge}$ & & & & .397 & -.165 & $-.282^{* *}$ \\
\hline & $(.158)$ & $(.084)$ & $(.056)$ & & & & $(.293)$ & $(.131)$ & $(.096)$ \\
\hline \multirow[t]{2}{*}{ education } & -.074 & $-.172^{*}$ & $-.310^{* * *}$ & $.203^{\wedge}$ & $-.280^{* *}$ & $-.292^{* * *}$ & -.223 & .090 & $-.228^{*}$ \\
\hline & $(.094)$ & $(.083)$ & $(.053)$ & $(.111)$ & $(.109)$ & $(.069)$ & $(.167)$ & $(.136)$ & $(.091)$ \\
\hline \multirow[t]{2}{*}{ job status } & & & & -.265 & .079 & $-.353^{* *}$ & & & \\
\hline & & & & $(.212)$ & $(.191)$ & $(.120)$ & & & \\
\hline \multirow[t]{2}{*}{ car ownership } & $3.060^{* * *}$ & .232 & .150 & $3.277^{* * *}$ & .476 & .304 & $3.483^{* * *}$ & .096 & .042 \\
\hline & $(.244)$ & $(.203)$ & $(.131)$ & $(.288)$ & $(.291)$ & $(.188)$ & $(.520)$ & $(.363)$ & $(.233)$ \\
\hline \multirow[t]{2}{*}{ work trip ${ }^{a}$} & $.495^{* *}$ & -.004 & $-.617^{* * *}$ & & & & & & \\
\hline & $(.186)$ & $(.161)$ & $(.100)$ & & & & & & \\
\hline distance from & $.271^{*}$ & $.364^{* * *}$ & $.182^{* *}$ & .086 & $.429^{* *}$ & .055 & $.631^{* *}$ & $.343^{*}$ & $.282^{* *}$ \\
\hline centre $^{\mathrm{b}}$ & $(.137)$ & $(.095)$ & $(.061)$ & $(.169)$ & $(.148)$ & $(.094)$ & $(.236)$ & $(.138)$ & $(.092)$ \\
\hline distance from & -.078 & $-.204^{* *}$ & -.016 & -.129 & $-.325^{* *}$ & .095 & & & \\
\hline $\mathrm{MRT}^{\mathrm{b}}$ & $(.099$ & $(.075)$ & $(.050)$ & $(.130)$ & $(.112)$ & $(.076)$ & & & \\
\hline \multicolumn{10}{|l|}{ density $^{b}$} \\
\hline \multirow[t]{2}{*}{ diversity $^{\mathrm{b}}$} & .270 & $-.385^{*}$ & .140 & & & & .528 & -.380 & $.378^{\wedge}$ \\
\hline & $(.221)$ & $(.177)$ & $(.111)$ & & & & $(.419)$ & $(.289)$ & $(.196)$ \\
\hline \multirow[t]{2}{*}{ design: slum } & $-.789^{*}$ & .096 & -.145 & $-1.269^{* *}$ & $.519^{*}$ & -.275 & & & \\
\hline & $(.332)$ & $(.191)$ & $(.122)$ & $(.472)$ & $(.263)$ & $(.179)$ & & & \\
\hline \multicolumn{10}{|c|}{ design: apartment } \\
\hline \multicolumn{10}{|c|}{ blocks } \\
\hline \multicolumn{10}{|l|}{ design: guarded } \\
\hline \multicolumn{10}{|l|}{ prop'ties } \\
\hline \multirow[t]{2}{*}{ city: São Paulo } & $-.718^{* *}$ & $-2.110^{* * *}$ & $-.890^{* * *}$ & $-.938^{* * *}$ & $-2.058^{* * *}$ & $-.651^{* * *}$ & -.463 & $-2.342^{* * *}$ & $-1.100^{* * *}$ \\
\hline & $(.226)$ & $(.239)$ & $(.137)$ & $(.268)$ & $(.299)$ & $(.197)$ & $(.421)$ & $(.485)$ & $(.241)$ \\
\hline \multirow[t]{2}{*}{ city: Mumbai } & $-2.298^{* * *}$ & $-.934^{* * *}$ & $-.857^{* * *}$ & $-2.623^{* * *}$ & $-1.942^{* * *}$ & $-.943^{* * *}$ & $-1.816^{*}$ & -.063 & $-.740^{* * *}$ \\
\hline & $(.452$ & $(.201)$ & $(.137)$ & $(.553)$ & $(.332)$ & $(.231)$ & $(.800)$ & $(.292)$ & $(.211)$ \\
\hline $\mathrm{n}$ & 2,832 & & & 1,253 & & & 1,102 & & \\
\hline Rho & $.162^{* * *}$ & & & $.174^{* * *}$ & & & $.138^{* * *}$ & & \\
\hline
\end{tabular}

reference category: public transport . ${ }^{* *} \mathrm{p}<.001{ }^{* *} \mathrm{p}<.01{ }^{*} \mathrm{p}<.05 \wedge \mathrm{p}<.1{ }^{\text {ajob status and work trip excluded from }}$ non-work trip models . ${ }^{b} \log$. Transformed 
Respondents with high socioeconomic status tend to drive and are less likely to walk in non-work trips. Walking is unlikely among respondents with a higher educational status; they tend to use formal public transport and the car in work trips. In work trips, formally employed respondents are less likely to walk than to ride public transit. If the trip maker travels for work, driving is preferred over public or para transit, which in turn are preferred over walking. Driving is the preferred mode among car owners.

Living at a larger distance to the metropolitan CBD is associated with less transit use, which applies to non-work trips in particular. Distance to MRT counters this pattern to some extent, wherein public transport is taken more often at a larger distance to MRT, when distance to the CBD is held constant.

Whereas density does not seem to be associated with mode choice, diversity reveals some relationship. In more mixed areas, walking and driving are more common than riding public or para transit. This pattern pertains mainly to non-work trips. Slum residents are less likely to drive and more likely to use para transit in work tips. This pattern may reflect effects of income in addition to social status as well as urban form constraints.

City dummies reflect the cities' different modal splits. In Istanbul, there is a general tendency towards public transport use and a more balanced use of para transit, driving and walking than in São Paulo and Mumbai. Para transit use is much less common in São Paulo than in the other two cities, while driving is less common in Mumbai.

\subsection{Linear models of trip duration}

Simple trip duration models highlight the significance of socio-demographic variables (Table 4). Trips made by men take longer than those made by women. Younger trip makers travel longer than older ones. More educated individuals take longer trips, while individuals with access to cars take shorter trips regardless of the mode chosen. 
Table 4: Coefficients and standard errors from simple and mode-adjusted OLS regression models of trip duration in the pooled sample.

\begin{tabular}{|c|c|c|c|c|c|c|c|}
\hline & all & & work & & & non-work & \\
\hline & simple & m.a. & simple & & m.a. & simple & m.a. \\
\hline \multirow[t]{2}{*}{ (intercept) } & $2.799^{* * *}$ & $2.681^{* * *}$ & $2.483^{* * *}$ & & $2.907^{* * *}$ & $2.816^{* * *}$ & $2.388^{* * *}$ \\
\hline & $(.225)$ & $(.097)$ & (.194) & & $(.171)$ & $(.318)$ & $(.143)$ \\
\hline \multirow[t]{2}{*}{ gender: female } & $-.121^{* * *}$ & & & & & $-.123^{*}$ & \\
\hline & $(.033)$ & & & & & $(.048)$ & \\
\hline \multirow[t]{2}{*}{ age } & $-.003^{*}$ & & & & & $-.003^{\wedge}$ & \\
\hline & $(.001)$ & & & & & $(.002)$ & \\
\hline \multirow[t]{2}{*}{ household size } & & & & & $.019^{\wedge}$ & & \\
\hline & & & & & $(.011)$ & & \\
\hline \multirow[t]{2}{*}{ social status } & & & & & & .036 & \\
\hline & & & & & & $(.024)$ & \\
\hline \multirow[t]{2}{*}{ education } & $.088^{* * *}$ & & .107 & $* * *$ & $.033^{\wedge}$ & .038 & \\
\hline & $(.015)$ & & $(.023)$ & & $(.018)$ & $(.025)$ & \\
\hline \multirow[t]{2}{*}{ job status ${ }^{a}$} & & & & & $-.077^{*}$ & & \\
\hline & & & & & $(.032)$ & & \\
\hline \multirow[t]{2}{*}{ car ownership } & $-.111^{* *}$ & $-.075^{*}$ & $-.197^{* *}$ & & $-.126^{*}$ & & \\
\hline & $(.038)$ & $(.033)$ & $(.061)$ & & $(.052)$ & & \\
\hline \multirow[t]{2}{*}{ work trip ${ }^{a}$} & $.198^{* * *}$ & $.076^{* *}$ & & & & & \\
\hline & $(.034)$ & $(.025)$ & & & & & \\
\hline \multirow[t]{2}{*}{ mode: walk } & & $-.649^{* * *}$ & & & $-.902^{* * *}$ & & $-.454^{* * *}$ \\
\hline & & $(.042)$ & & & $(.068)$ & & $(.061)$ \\
\hline \multirow[t]{2}{*}{ mode: public transport } & & $.543^{* * *}$ & & & $.505^{* * *}$ & & $.541^{* * *}$ \\
\hline & & $(.044)$ & & & $(.066)$ & & $(.069)$ \\
\hline \multirow[t]{2}{*}{ mode: car } & & $-.137^{*}$ & & & $-.190^{*}$ & & -.149 \\
\hline & & $(.060)$ & & & $(.086)$ & & $(.093)$ \\
\hline \multirow[t]{2}{*}{ distance from centre ${ }^{b}$} & $-.044^{*}$ & & & & & $-.054^{*}$ & \\
\hline & $(.019)$ & & & & & $(.023)$ & \\
\hline \multicolumn{8}{|l|}{ distance from $\mathrm{MRT}^{\mathrm{b}}$} \\
\hline \multicolumn{8}{|l|}{ density $^{b}$} \\
\hline \multirow[t]{2}{*}{ diversity $^{b}$} & $-.197^{* * *}$ & $-.149^{* * *}$ & $-.137^{*}$ & & $-.138^{* *}$ & $-.258^{* * *}$ & $-.222^{* * *}$ \\
\hline & $(.037)$ & $(.029)$ & $(.059)$ & & $(.044)$ & $(.051)$ & $(.041)$ \\
\hline \multirow[t]{2}{*}{ design: slums } & $.164^{* * *}$ & $.125^{* * *}$ & $.220^{* * *}$ & & $.161^{* *}$ & & \\
\hline & $(.043)$ & $(.035)$ & $(.067)$ & & $(.051)$ & & \\
\hline \multirow[t]{2}{*}{ design: apartment blocks } & $-.134^{* * *}$ & $-.112^{* * *}$ & $-.195^{* *}$ & & $-.127^{*}$ & $-.214^{* * *}$ & $-.152^{* * *}$ \\
\hline & $(.038)$ & $(.033)$ & $(.067)$ & & $(.051)$ & $(.051)$ & $(.041)$ \\
\hline \multirow[t]{2}{*}{ design: guarded properties } & & $-.079^{\wedge}$ & & & & $-.213^{* *}$ & $-.161^{* *}$ \\
\hline & & $(.044)$ & & & & $(.067)$ & $(.057)$ \\
\hline \multirow[t]{2}{*}{ city: São Paulo } & $.273^{* * *}$ & $.139^{* * *}$ & $.198^{* *}$ & & $.189^{* * *}$ & $.139^{*}$ & \\
\hline & $(.046)$ & $(.039)$ & $(.073)$ & & $(.051)$ & $(.068)$ & \\
\hline \multirow[t]{2}{*}{ city: Mumbai } & $.091^{*}$ & $-.060^{\wedge}$ & $.195^{* *}$ & & & & -.066 \\
\hline & $(.041)$ & $(.032)$ & $(.070)$ & & & & $(.041)$ \\
\hline $\mathrm{n}$ & 2,953 & 2,821 & 1,330 & & 1,248 & 1,135 & 1,097 \\
\hline $\mathrm{R}^{2}$ & $.117^{* * *}$ & $.462^{* * *}$ & $.059^{* * *}$ & & $.493^{* * *}$ & $.095^{* * *}$ & $.355^{* * *}$ \\
\hline
\end{tabular}

Dependent variable: log. trip duration · m.a.: mode-adjusted models $\cdot{ }^{* * *} \mathrm{p}<.001{ }^{* *} \mathrm{p}<.01{ }^{*} \mathrm{p}<.05 \wedge \mathrm{p}<.1 \cdot{ }^{\mathrm{a}} \mathrm{job}$ status and work trip excluded from non-work trip models . blog. transformed 
Yet, these patterns nearly disappear in mode-adjusted models. Here, shorter trip duration is associated, first, with walking and, second, with driving, whereas longer trip duration is associated with the use of public transport. Car ownership and education remain associated in work trips. In terms of geographic context, trips originating distant from the center tend to be shorter than others, but this pattern is also accounted for by mode choice.

Density is not associated with trip duration, but higher diversity is associated with shorter trips. The design variables also show associations. Trip makers who live in slums tend to make longer trips in all cities, while those living in apartment blocks make shorter trips. Trip makers in guarded properties travel for a shorter time in non-work trips.

Consistent with the descriptive results, trip lengths generally vary across the cities in addition to the potential effect of city-specific modal splits. Paulistanos travel longer than Istanbulites and Mumbaikars in both work and non-work trips. This city divide weakens in non-work trips, however. Mumbaikars tend to make shorter non-work trips.

\section{Common versus divergent patterns: Findings and interpretations}

The comparison of city-wise models unmasks divergent patterns, which — building up on the common determinants - may be summarized as six findings (Table 5).

Table 5: The main patterns and their applicability to the cities.

\begin{tabular}{lccc}
\hline pattern & Sáo Paulo & Istanbul & Mumbai \\
\hline $\begin{array}{l}\text { 1. Mode choice is socially distributed; trip duration responds } \\
\text { to the built environment. }\end{array}$ & + & + \\
\hline $\begin{array}{l}\text { 2. Gender and household organisation affect travel demand } \\
\text { differentially }\end{array}$ & ++ & + \\
\hline $\begin{array}{l}\text { 3. Car ownership is the strongest determinant of mode choice } \\
\text { where car use is common. }\end{array}$ & - & + \\
\hline $\begin{array}{l}\text { 4. Informal settlements can provide a high degree of compact- } \\
\text { ness and accessibility. }\end{array}$ & + & + \\
\hline $\begin{array}{l}\text { 5. Transport disadvantage may be attenuated in more decen- } \\
\text { tralised urban regions. }\end{array}$ & + \\
\hline $\begin{array}{l}\text { 6. The built environment remains relevant, exhibiting diverse } \\
\text { effects. }\end{array}$ & + & + \\
\hline
\end{tabular}

key: + applies to city o no evidence/not applicable - reverse applies to city

\subsection{Mode choice is socially distributed; trip duration responds to the built environment.}

In all cities, the mode chosen is primarily a joint result of the social circumstances of the trip maker and the distance of the travel destination from the residence. The contribution of the built environment to mode choice models is low; they rarely exceed three percent (Table 6). Built environment characteristics are associated most with mode choice in non-work trips.

Trip duration, on the other hand, responds more to geographical context and built environment characteristics than to social circumstances, once mode choice is accounted for. Associations with the 
built environment are strongest in Mumbai with contributions of between five to 11 percent. The stronger land use-transport relationship in Mumbai might be interpreted, first, in terms of efficiency, whereby mixed areas provide better accessibility compared to non-mixed areas, second, network constraints including less scope for route choices and effectiveness of time-of-day choices of travel, and third, residential self-selection, whereby some respondents deliberately locate in proximity to their regular destinations to avoid longer travel and congestion.

\subsection{Gender and household organization affect travel demand differentially.}

Consistent with work on gender and transport by others (e.g., Tran $\&$ Schlyter, 2010), the models reveal a higher instance of walking among women. Men, on the other hand, travel farther distances for work, shopping and other non-work destinations.

Yet, Dominance Analysis suggests that, in Mumbai, gender is three times and eight to ten times more important than in Istanbul and São Paulo respectively. Indeed, in Mumbai, gender dominates the role of social status, whereas in São Paulo and Istanbul, social status constitutes a better predictor of mode choice. Since in contemporary India, women are rarely the head of household and tend to join their husband's household after marriage, household locations may generally reflect more the needs of the male head of household. Location and mobility resources are organized around the male employment, whereas women seek employment in the nearby environment or need to travel longer for work. The findings by Mahadevia, and Advani (2016) render this interpretation plausible for Mumbai.

Cultural institutions of household organization, division of labor and status of women are thus deeply implicated in shaping the mobility context of a household in Mumbai. In contrast, in São Paulo, lower car use and longer trip distances for work can be observed for members of large households, while the distribution of household responsibilities appear to be less gendered. 
Table 6: Variance partition in city-wise models.

\begin{tabular}{|c|c|c|c|c|c|c|c|c|c|c|}
\hline & \multirow[t]{2}{*}{ trend $\left.^{a}\right)$} & \multicolumn{3}{|c|}{ all trips } & \multicolumn{3}{|c|}{ work trips } & \multicolumn{3}{|c|}{ non-work trips } \\
\hline & & SPO & IST & MBI & SPO & IST & MBI & $\mathrm{SPO}$ & IST & MBI \\
\hline \multicolumn{11}{|l|}{ mode choice ${ }^{b}$} \\
\hline 1 gender & $+\mathrm{i}+\mathrm{w}$ & 0.4 & 1.0 & 3.2 & 0.6 & 1.8 & 0.5 & 1.5 & & 3.3 \\
\hline 2 age & $-p$ & 1.2 & 0.9 & 1.2 & 1.2 & 1.8 & & & & 2.1 \\
\hline 3 household size & $-\mathrm{p}$ & & & 0.5 & & & 1.7 & $\underline{1.0}$ & & \\
\hline 4 social status & $+\mathrm{c}-\mathrm{w}$ & 3.1 & & & & & & 3.9 & & 1.3 \\
\hline 5 education & $+c+p$ & 1.4 & 2.7 & 1.4 & 3.6 & 1.0 & & $\underline{1.0}$ & 3.8 & 1.2 \\
\hline 6 job status ${ }^{c}$ & $+p$ & 0.7 & 2.1 & & 1.3 & 1.5 & & & & \\
\hline 7 car ownership & $+\mathrm{c}+\mathrm{i}$ & 4.8 & 7.6 & & 7.4 & 13.6 & & 6.8 & 6.3 & \\
\hline 8 work trip ${ }^{c}$ & $+\mathrm{c}$ & 0.5 & 2.1 & 3.3 & & & & & & \\
\hline 9 distance from centre ${ }^{d}$ & $+\mathrm{i}+\mathrm{w}$ & $\underline{0.3}$ & & 2.3 & $\underline{0.5}$ & $\underline{0.6}$ & 2.5 & & & 3.1 \\
\hline 10 distance from $\mathrm{MRT}^{\mathrm{d}}$ & $-\mathrm{i}+\mathrm{w}$ & 0.4 & & 0.4 & 0.8 & & & & & 1.4 \\
\hline 11 density $^{d}$ & $+\mathrm{i}+\mathrm{w}$ & & 0.5 & 0.4 & & & $\underline{1.2}$ & & 0.9 & 0.7 \\
\hline 12 diversity $^{d}$ & $-\mathrm{i}+\mathrm{w}$ & 0.8 & & 0.2 & & & & & & 1.3 \\
\hline \multicolumn{11}{|l|}{13 design } \\
\hline slums & $-c+i+w$ & 1.7 & & 0.6 & 2.9 & 1.1 & 1.7 & & & \\
\hline apartment blocks & $-p$ & 0.4 & & 0.6 & 0.6 & & 0.8 & & 1.1 & 1.1 \\
\hline \multicolumn{11}{|l|}{ guarded properties } \\
\hline $\mathrm{n}$ & & 931 & 935 & 957 & 558 & 298 & 391 & 219 & 476 & 404 \\
\hline rho (MacFadden) & & 15.8 & 17.0 & 14.2 & 19.0 & 21.5 & 8.4 & 14.2 & 12.1 & 15.5 \\
\hline built environment & & 2.9 & 0.5 & 1.8 & 3.5 & 1.1 & 3.7 & 0.0 & 1.9 & 31.1 \\
\hline \multicolumn{11}{|l|}{ trip duration $^{\mathrm{d}}$} \\
\hline 1 gender & - & & & & & & $\underline{0.7}$ & & & 2.3 \\
\hline 2 age & - & & $\underline{0.2}$ & 0.5 & & & & & & \\
\hline 3 household size & + & 0.6 & & & 1.0 & & & & & \\
\hline 4 social status & + & & 1.2 & & & & & & 1.9 & \\
\hline 5 education & + & & & & & 1.4 & & $\underline{0.8}$ & & \\
\hline 6 job status ${ }^{c}$ & - & & 0.5 & & & 0.5 & & & & \\
\hline 7 car ownership & - & 0.6 & & & 1.2 & & & & 0.3 & \\
\hline 8 work trip ${ }^{c}$ & + & & & 5.8 & & & & & & \\
\hline \multicolumn{11}{|l|}{9 mode } \\
\hline walk & - & 22.6 & 20.9 & 17.0 & 26.1 & 23.7 & 22.6 & 24.5 & 17.8 & 11.2 \\
\hline public transport & + & 19.1 & 13.5 & 25.1 & 19.7 & 14.4 & 27.7 & & 11.2 & 22.0 \\
\hline $\mathrm{car}$ & - & 2.2 & 1.1 & 0.3 & 2.3 & 2.0 & 0.5 & 7.6 & & \\
\hline 10 distance from centre & - & $\underline{0.4}$ & & 0.6 & $\underline{0.8}$ & & 1.0 & & 1.1 & \\
\hline 11 distance from $\mathrm{MRT}^{\mathrm{d}}$ & + & & 0.5 & & & 1.2 & & & 0.7 & \\
\hline 12 density $^{d}$ & - & & & 0.1 & & & & & 0.6 & 0.7 \\
\hline 13 diversity $^{\mathrm{d}}$ & - & & 0.5 & 2.4 & & 1.3 & 0.5 & & & 7.4 \\
\hline 14 design & & - & - & - & - & - & - & - & - & - \\
\hline slums & + & 1.2 & & & & 2.9 & & 2.7 & $\underline{0.2}$ & \\
\hline apartment blocks & - & & & 3.3 & & & 4.9 & & & 3.1 \\
\hline guarded properties & - & & 0.8 & & 0.3 & 0.5 & & & 1.6 & \\
\hline $\mathrm{n}$ & & 953 & 942 & 968 & 572 & 299 & 397 & 222 & 83 & 407 \\
\hline $\mathrm{R}^{2}$ & & 46.6 & 39.1 & 55.2 & 51.4 & 48.0 & 57.8 & 35.6 & 35.3 & 46.8 \\
\hline built environment & & 1.2 & 1.3 & 5.8 & 0.3 & 4.7 & 5.4 & 2.7 & 2.4 & 11.2 \\
\hline
\end{tabular}

underlined figures indicate opposing trend, see note aSPO: São Paulo · IST: Istanbul · MBI: Mumbai · ${ }^{a}$ trends: + positive association, - negative association, $\mathrm{c}$ car, i para transit, $\mathrm{p}$ public transport, $\mathrm{w}$ walk $\cdot{ }^{\mathrm{b}} \mathrm{car}$ excluded from alternatives in Mumbai. c job status and work trip excluded in non-work trips. ${ }^{d} \log$. transformation 


\subsection{Car ownership is the strongest determinant of mode choice where car use is common.}

Members of car-owning households tend to drive; and this puts motorization into focus as a general determinant of urban mobility. At the same time, car owners also make shorter trips independent from whether they actually drive. Two tendencies may explain this finding: first, car-owning households settle in more accessible locations; second, due to experience of private mobility, the tolerance of using other modes for longer trips is lower.

The models in Istanbul and São Paulo support both explanations. Members of car-owning households who do not use the car in work trips appear to work more often in the vicinity while the car is used by another individual (perhaps the main earner) to reach a more distant workplace. Household location decisions may be made to satisfy the preference for auto-mobility while avoiding the cost of a second vehicle. In São Paulo, higher status households often live in more accessible locations, which exacerbates issues of transport inequity (see also Boisjoly, Moreno-Monroy, \& El-Geneidy, 2017).

On this basis, it may be expected that mode choice becomes more aligned with status in Mumbai in the future, as motorization expands. Since in Mumbai, work trips encourage public transit, it appears that public transport still provides those functions the car fulfils in São Paulo and Istanbul: motorized transportation over medium and longer distances.

\subsection{Informal settlements can provide a high degree of compactness and accessibility.}

The travel choices of slum dwellers indicate different functions of slums in the urban settlement systems. Mumbai slums (and their surroundings), where residents tend to walk more often to their destination, host more informal functions including employment and services than slums in São Paulo. In contrast, Paulistanos need to leave favelas in order to exercise their work and non-work activities; they require motorization through para transit. In consequence, Paulistano slum dwellers travel longer than other residents in non-work trips. In Istanbul, slum dwellers travel longer for work trips and shorter for nonwork trips. Travel demand thus suggests that gecekondus are better integrated into the urban fabric than São Paulo favelas.

\subsection{Transport disadvantage may be attenuated in more decentralized urban regions.}

Despite lower service levels in peripheral parts of the Sáo Paulo and Istanbul metropolitan regions, residents living further from the CBD use public transport more often than other modes. Since car ownership is taken into account and is strongly associated with driving, it is likely that these patterns reflect a degree of mode captivity among households without access to a car. These residents are likely forced to spend significantly more time on travel. Indeed, in Sáo Paulo, trips from peripheral locations tend to be longer, while, in Istanbul, longer work and non-work trips are made by respondents who live farther from the MRT network.

By contrast, Mumbaikars living further away from the center walk or take para transit. This pattern suggests that trip makers either satisfy their travel purpose within shorter distance within the polycentric structure, where para transit fills in service gaps of public transport. In addition, there is a weak tendency for trips to be shorter in peripheral areas, which in comparison suggests that Mumbai's more compact and polycentric structure may ease transport disadvantage.

The differential impact of modes on trip duration supports this reasoning. The 'shortening' impact of walking on trip duration in the models is considerably higher in São Paulo than in Istanbul or Mumbai because motorized trips in Sáo Paulo are much longer in comparison. By contrast, trips made by public transport in Mumbai are significantly longer relative to city average, while, in Istanbul, public 
transport adds least in terms of extra travel time. These cross-city tendencies are most extreme in nonwork trips, suggesting that Mumbai respondents enjoy better non-work accessibility than Istanbulites, not to mention Paulistanos.

The divergent patterns reveal the ways in which the different transport systems function in interaction with urban structure. Istanbul's urban form is relatively compact and the transport system may be comparatively efficient; hence, distances and speed of transit keep trip duration closer to the average trip length. In São Paulo, public transport adds more time to trips due to the larger distances it covers. In Mumbai, extreme dense urban form in conjunction with the quality and organization of public transport makes this mode more susceptible to congestion.

\subsection{The built environment remains relevant, exhibiting diverse effects.}

Dense areas show shorter trips and thus potentially increase the attractiveness of walking; yet, this potential not always materializes. High density areas are associated with a higher instance of walking in Istanbul and Mumbai in non-work trips. But Mumbaikars also take para transit in high density areas, and, in fact, are less likely to walk in work trips. A possible hypothesis is that congestion and reduced walkability in Mumbai's hyper-dense neighborhoods may counter the potential ease of walking, and the most efficient mode in this context is the small, informal vehicle, which in heavy traffic is still relatively safe and mobile. This suggests that there might be levels of density that are counter-productive, depending on the capacity of the transport network.

Diversity is widely associated with shorter trip durations, increased instance of walking but also driving. In Istanbul and Mumbai, it seems that higher diversity allows better actualization of both work and non-work activities in the vicinity. Diversity contributes substantially to trip duration in Mumbai's non-work trips and to a lesser degree in work trips, again highlighting the stronger land use-transport relationship found in the city.

Table 7: Model elasticities of selected D variables.

\begin{tabular}{|c|c|c|c|}
\hline city & trip & association & elasticity \\
\hline \multirow[t]{4}{*}{ São Paulo } & work & driving $\sim$ slum residence & -.212 \\
\hline & & walking - slum residence & -.151 \\
\hline & & travel time - distance to CBD & .243 \\
\hline & non-work & travel time - slum residence & .014 \\
\hline \multirow[t]{5}{*}{ Istanbul } & work & driving - slum residence & -.089 \\
\hline & & travel time - distance to MRT & .230 \\
\hline & & travel time - diversity & -.206 \\
\hline & non-work & travel time $\sim$ distance to MRT & .258 \\
\hline & & travel time - diversity & -.206 \\
\hline \multirow[t]{6}{*}{ Mumbai } & work & public transport - density & .957 \\
\hline & & walking - slum residence & .183 \\
\hline & & travel time $\sim$ diversity & -.128 \\
\hline & non-work & walking - diversity & -.805 \\
\hline & & travel time - density & -.394 \\
\hline & & travel time - diversity & -.353 \\
\hline
\end{tabular}


Trip duration models suggest that neighborhoods with apartment blocks provide greater ease of travel. Trips are shorter in all trips in Mumbai and in non-work trips in Istanbul. Since other factors such as social status or access to services are controlled for, this patterns might be attributed to a design effect of apartment block neighborhoods; they might be more permeable. Indeed, the instance of walking in such neighborhoods is higher in Istanbul and Mumbai. But Mumbaikars also favor para transit, which points again to the greater substitution relationship between para transit and walking in the city. In São Paulo, there is a tendency of apartment block residents to use the car more often.

Slums are often associated with longer trips in São Paulo and Istanbul, while in guarded properties in Sáo Paulo and Istanbul, trips for work and non-work destinations tend to be shorter. A possible explanation could be that the latter areas are better structured and less obstructed from a traffic perspective. Elasticities of density and diversity range between -.15 and -.40 in trip duration models in Istanbul and Mumbai (Table 6). The values are strongest in non-work trips in Istanbul and Mumbai. In São Paulo, geographical location in the metropolitan region dominates the potential effects of the local built environment. Elasticities are generally higher than those reported for Vehicle Miles Travelled (VMT) in the review by Ewing and Cervero (2010). But differences in measures (VMT versus trip duration) and calculations (average versus point elasticities) yield at best a general impression of the different effect of the built environment in the three metropolitan regions compared to cities in advanced economies.

\section{Discussion}

\subsection{Considerations for transport policy}

The comparative strategy foregrounds the diverse ways in which social, cultural, geographical and built environment characteristics affect travel and how households are placed differentially at risk of disadvantage within different socio-spatial contexts. On the whole, some support arises for the hypothesis of a stronger transport-land use interaction in the three cities with respect to trip duration, whereas mode choice is more associated with the distinct socio-cultural and geographical conditions in the regions. But important variations arise within this tendency, and these warrant further research based on larger samples.

The findings so far suggest different policy priorities for each city. In São Paulo, social exclusion in transport is reflected in longer trips by socially disadvantaged groups in the context of dispersed settlements and lower public transport accessibility. In comparison with the other cities, Paulistano slum dwellers and residents with lower social status appear worse off and car owners better off than elsewhere. There is hence a need to improve mobility for peripheral and favela residents through an emphasis on extending public transport and supporting informal modes, potentially including emerging car sharing services. A high-level strategy of decentralized concentration possibly in form of transit-oriented development, as indeed envisioned in São Paulo’s master plan (Prefeitura de São Paulo, 2015), may help reduce travel distances in the long run. Since motorization is advanced, strong fiscal policies to discourage driving may be appropriate, if a safe and affordable public transport network can be developed.

In Istanbul, priorities should center on discouraging vehicle acquisitions, because the level of motorization is still lower and car ownership emerges as a significant determinant in mode choice. Further development of the transport network with characteristics that appeal to middle class households may be part of this solution and are indeed prominent in Istanbul's current transport strategy (IDA, 2014). But given the city's topographic constraints, economic development and policy bias towards deregulation (Terzi \& Bölen, 2012), large-scale interventions into land use and transport may make socially disadvantaged groups more susceptible to displacement into less accessible locations. Hence, mixed and equitable land-use planning and the support and expansion of basic, local transport services, which includes the dolmuş, is vital for the long-term mobility of all groups. 
In Mumbai, there is an urgent need to support the function of public transport that the car increasingly fulfils in the other two cities. A granular public transport network that is as unaffected as possible by private vehicles emerges as key concern, while para transit should be supported in their role of providing service in the metropolitan periphery. Recognizing the strongly gendered nature of travel choices in Mumbai, a focus on local accessibility and safe walkability in both very dense and more peripheral areas would support women and poorer households (see also Shirgaokar, 2014), whose mobility and livelihood needs are at risk of being unmet by a policy emphasis on functional segregation, centerconnectivity and other large-scale supply side investments. Finally, orientating land-use strategies along the region's decentralized structure may reduce the need for travel in the region.

\subsection{Study limitations}

Conducting comparative research in three very different emerging economy cities is a challenging undertaking. Although data collection, sampling and consistency were central to this endeavor, outcomes in terms of data coverage, quality and validity were not always the ones desired. As a result, this study faces data limitations much like other travel demand studies in emerging economy contexts.

First and foremost to mention are the sample sizes that were achievable with the resources available. As a consequence, the present statistical power causes higher uncertainty in the modelling, as reflected in standard errors. Case weights and the geographic sampling were applied to maximize statistical robustness, but better powered surveys would be desirable to verify some of the findings.

Lack of comprehensive land-use data likely cause inaccuracies in measuring land-use diversity, which in the present study relies on subjective assessments without clear attribution of mode choice. In order to at least in parts address the resulting uncertainty, individual travel time estimates were averaged for each the sampling point. Some informal comparison of the resulting values with OpenStreetMap data yielded plausible results, but for future research, better land-use descriptors would be desirable. Other variables that might be affected by the vagaries of self-reporting are trip duration, interchanges and mode choice.

The sampling points themselves present some uncertainty, and individual address-level data would have yielded more precise estimates of geographical and built environment characteristics. Precise address data were not used due to confidentiality assurances made as part of the interviewee recruitment. Similarly, a trip maker's destination and its characteristics were not collected but would have presented further valuable data on the built environment.

With regard to distance to CBD and distance to MRT, there might be some inaccuracies resulting from the quality and collection period of data available in OpenStreetMap. Road segments may not have existed at the time of the studies and records may be incomplete particularly in more peripheral parts of the region. Nevertheless, results appear robust to alternative measurements, such as simple Euclidean distances.

Dummies for settlement typology used as design variables may encompass diverse physical configurations across cities. Even within a city, an older established slum may differ strongly from younger slums in terms of design characteristics, services and social organization. On the other hand, the settlement typology generated some relevant results, and these elements may still be useful in addition to continuous design variables in the absence of reliable data on neighborhood design. OpenStreetMap might present an alternative data resource, but, at this time the completeness is questionable and heavily skewed towards centrally located and formal settlements.

The age-censored sample only allows making inferences about the cities' working age populations. Although only five to seven percent of the cities' inhabitants are actually above 65, the experiences of this more vulnerable group are important for planning and should be the subject of future transportation research in emerging economies, in particular as they undergo demographic transition. 
Residential self-selection was not directly controlled for in the model due to absence of attitudinal data or information that related to decisions of residential location. In order to at least attain a general sense of potential selection effects, separate OLS and logit models of geographical and built environment characteristics with socio-demographics as independent variables were run. Although the models rarely account for more than three percent of the variance, higher status households in São Paulo and Istanbul show a tendency of living in better accessible and more central locations. This might in parts explain the weaker land use-transport relationship in the two cities. In Mumbai, on the other hand, selection effects may still be larger than expected. Low income workers tend to seek accommodation close to employment opportunities, and in so doing do not access the formal housing sector (Nijman, 2008). Selection by low income groups may thus counter selection by high income groups. The residential mobility of informal settlers within emerging economy cities is under-researched and presents itself as another important subject for future travel demand research.

\section{Concluding remarks}

Despite these limitations, the simultaneous study of São Paulo, Istanbul and Mumbai uniquely generates evidence of diverse causal processes that are involved in shaping travel demand in these cities. The variation-finding, comparative design, offers contextual insights beyond both aggregate studies of city level indicators and single city micro-level studies. Comparison expands the focus from individual mobility practices towards broader urban structural, institutional and socio-cultural conditions, and serves the need to balance the general and the particular in transport research and policy (Schwanen, 2016, p. 2).

In particular, it is shown that social equity issues appear in different guises and are differently implicated in transport land-use relationships in the cities. While continuing trends of declining mobility, urban sprawl, motorization and prioritization of auto-mobility intensify the everyday experience of social exclusion, current emphases on sustainable travel in some of the cities' strategies offer some hope that socially exclusive scenarios of automobile-dependence can be avoided. Further comparative research on the variegated determinants of travel demand may evaluate the effects of these policies and assess under what socio-spatial conditions they successfully deliver sustainable and inclusive urban mobility.

\section{Acknowledgements}

The field work and data collection was supported by Alfred Herrhausen Society as part of the Urban Age grant held by LSE Cities, London School of Economics and Political Science (https://urbanage. lsecities.net/). The work for this paper builds on the Urban Age City Survey project (https://secities. net/objects/research-projects/urban-age-city-survey-mumbai) led by Philipp Rode, LSE Cities, London School of Economics and Political Science. I wish to thank Philipp for his crucial, managerial support in the context of the project. I am extremely grateful to Joachim Scheiner and Alexandra Hill for their instructive feedback at an earlier stage of this work, and I thankfully acknowledge Annette Spellerberg for her comments on an earlier draft of this paper. 


\section{References}

Adeel, M., Yeh, A. G. O., \& Zhang, F. (2016). Transportation disadvantage and activity participation in the cities of Rawalpindi and Islamabad, Pakistan. Transport Policy, 47, 1-12. doi.org/10.1016/j. tranpol.2015.12.001

Ahmad, S., \& Puppim de Oliveira, J. A. (2016). Determinants of urban mobility in India: Lessons for promoting sustainable and inclusive urban transportation in developing countries. Transport Policy, 2030, 1-9. doi.org/10.1016/j.tranpol.2016.04.014

Ahmed, Q. I., Lu, H., \& Ye, S. (2008). Urban transportation and equity: A case study of Beijing and Karachi. Transportation Research Part A: Policy and Practice, 42(1), 125-139. doi.org/10.1016/j. tra.2007.06.004

Azen, R., \& Budescu, D. V. (2003). The dominance analysis approach for comparing predictors in multiple regression. Psychological Methods, 8(2), 129-148. doi.org/10.1037/1082-989X.8.2.129

Ben-Akiva, M., \& Lerman, S. R. (1985). Discrete choice analysis: Theory and Application to travel demand. Cambridge, MA: MIT Press.

Bharadwaj, S., Ballare, S., Rohit, M. K., \& Chandel. M. K. (2017). Impact of congestion on greenhouse gas emissions for road transport in Mumbai metropolitan region. Transportation Research Procedia, 25, 3538-3551. doi.org/10.1016/j.trpro.2017.05.282

Boisjoly, G., Moreno-Monroy, A. I., \& El-Geneidy, A. (2017). Informality and accessibility to jobs by public transit: Evidence from the São Paulo Metropolitan Region. Journal of Transport Geography, 64, 89-96. doi.org/10.1016/j.jtrangeo.2017.08.005

Cervero, R. (2013). Linking urban transport and land use in developing countries. Journal of Transport and Land Use, 6, 7-24. doi.org/10.5198/jtlu.v1.425

Cervero, R., \& Kockelman, K. (1997). Travel demand and the 3Ds: Density, diversity, and design. Transportation Research Part D: Transport and Environment, 2(3), 199-219. doi.org/10.1016/S13619209(97)00009-6

Croissant. (2013). mlogit: multinomial logit model. R package version 0.2-4. Retrieved from http:// CRAN.R-project.org/package $=$ mlogit

Daily Sabah. (2014). Study: Istanbul's heavy traffic congestion damaging to economy. Daily Sabah. Retrieved from https://www.dailysabah.com/turkey/2014/12/09/study-istanbuls-heavy-traffic-congestion-hurtful-for-economy

de Vasconcellos, E. A. (2005). Urban change, mobility and transport in São Paulo: Three decades, three cities. Transport Policy, 12(2), 91-104. doi.org/10.1016/j.tranpol.2004.12.001

Domencich, T. A., \& McFadden, D. (1975). Urban travel demand. A behavioral analysis. Amsterdam: North-Holland Publishing Company.

Ewing, R. \& Cervero, R. (2010). Travel and the built environment. Journal of the American Planning Association, 76(3), 265-294. doi.org/10.1080/01944361003766766

Feng, J., Dijst, M., Prillwitz, J., \& Wissink, B. (2013). Travel time and distance in international perspective: A comparison between Nanjing (China) and the Randstad (The Netherlands). Urban Studies, 50(14), 2993-3010. doi.org/10.1177/0042098013482504

Gakenheimer, R. (2011). Land use and transport in rapidly motorizing cities: Contexts of controversy. In H. T. Dimitriou \& R. Gakenheimer (Eds.), Urban transport in the developing world: A handbook of policy and practice (pp. 40-68). Cheltenham, UK: Edward Elgar Publishing.

Gakenheimer, R. (1999). Urban mobility in the developing world. Transportation Research Part A: Policy and Practice, 33(7-8), 671-689. doi.org/10.1016/S0965-8564(99)00005-1

Gerçek, H. (2009). Is there a road ahead? In R. Burdett (Ed.), Istanbul: City of intersections (p. 47). London: Urban Age Program, London School of Economics and Political Science. 
Grömping, U. (2006). Relative importance for linear regression in R: The package relaimpo. Journal of Statistical Software, 17(1), 1-27. doi.org/10.18637/jss.v017.i01

Guerra, E. (2015). The geography of car ownership in Mexico City: A joint model of households' residential location and car ownership decisions. Journal of Transport Geography, 43, 171-180. doi. org/10.1016/j.jtrangeo.2015.01.014

Huang, X., Cao, X., \& Cao, J. (2016). The association between transit access and auto ownership: Evidence from Guangzhou, China. Transportation Planning and Technology, 39(3), 269-283. doi.org/1 $0.1080 / 03081060.2016 .1142223$

IDA. (2014). 2014 - 2023 Istanbul regional plan. (Istanbul Development Agency). Retrieved from http://www.istka.org.tr/media/24723/istanbul-regional-plan-2014-2023.pdf

IMM. (2016). Istanbul transport annual report 2016. (Istanbul Metropolitan Municipality). Retrieved from https://tuhim.ibb.gov.tr/media/2131/imm_transport_report.pdf

Kezič, M. E. L., \& Durango-Cohen, P. L. (2012). The transportation systems of Buenos Aires, Chicago and Sao Paulo: City centers, infrastructure and policy analysis. Transportation Research Part A: Policy and Practice, 46(1),102-122. doi.org/10.1016/j.tra.2011.09.007

Kenworthy, G. R. (2017). Is automobile dependence in emerging cities an irresistible force? Perspectives from São Paulo, Taipei, Prague, Mumbai, Shanghai, Beijing, and Guangzhou. Sustainability, 9(11), 1953-1983. doi.org/10.3390/su9111953

Kutzbach, M. J. (2009). Motorization in developing countries: Causes, consequences, and effectiveness of policy options. Journal of Urban Economics, 65(2), 154-166. doi.org/10.1016/j.jue.2008.10.002

Larrañaga, A. M., Rizzi, L. I., Arellana, J., Strambi, O., \& Cybis, H. B. B. (2016). The influence of built environment and travel attitudes on walking: A case study of Porto Alegre, Brazil. International Journal of Sustainable Transportation, 10(4), 332-342. doi.org/10.1080/15568318.2014.933986

Lin, J. J., \& Yang, A. T. (2009). Structural analysis of how urban form impacts travel demand: Evidence from Taipei. Urban Studies, 46(9), 1951-1967. doi.org/10.1177/0042098009106017

Lindeman, R., Merenda, P. F., \& Gold, R. Z. (1980). Introduction to bivariate and multivariate analysis. Glenview, US: Scott, Foresman.

Lucas, K., \& Porter, G. (2016). Mobilities and livelihoods in urban development contexts: Introduction. Journal of Transport Geography, 55, 129-131. doi.org/10.1016/j.jtrangeo.2016.07.007

Lucinda, C., Ledo, B., \& Meyer, L. (2013). Congestion charge in São Paulo city: Likely traffic effects. (Working paper 74). Washington, DC: Global Development Network GDN.

Luchman, J. N. (2014). Relative importance analysis with multicategory dependent variables: An extension and review of best practices. Organizational Research Methods, 17(4), 452-471. doi. org/10.1177/1094428114544509

Ma, J., Mitchell, G., \& Heppenstall, A. (2014). Daily travel behavior in Beijing, China: An analysis of workers' trip chains, and the role of socio-demographics and urban form. Habitat International, 43, 263-273. doi.org/10.1016/j.habitatint.2014.04.008

Mahadevia, D., \& Advani, D. (2016). Gender differentials in travel pattern - the case of a mid-sized city, Rajkot, India. Transportation Research Part D: Transport and Environment, 44, 292-302. doi. org/10.1016/j.trd.2016.01.002

Manoj, M., \& Verma, A. (2016). Effect of built environment measures on trip distance and mode choice decision of non-workers from a city of a developing country, India. Transportation Research Part D, 46, 351-364. doi.org/10.1016/j.trd.2016.04.013

Manoj, M., \& Verma, A. (2015). Activity-travel behavior of non-workers belonging to different income group households in Bangalore, India. Journal of Transport Geography, 49, 99-109. doi.org/10.1016/j. jtrangeo.2015.10.017 
Manoj, M., Verma, A., \& Navyatha, M. (2015). Commute travel and its effect on housing tenure choice of males and females living in the urban and rural areas of Bangalore city in India. Journal of Transport Geography, 45, 62-69. doi.org/10.1016/j.jtrangeo.2015.05.001

MCGM. (2016). Comprehensive mobility plan (CMP) for Greater Mumbai. (Municipal Corporate of Greater Mumbai). Retrieved from http://portal.mcgm.gov.in

MMRDA. (2016). Draft Mumbai metropolitan regional plan 2016-2036. (Mumbai Metropolitan Region Development Authority). Retrieved from https://mmrda.maharashtra.gov.in/regional-plan

Nijman, J. (2008). Against the odds: Slum rehabilitation in neoliberal Mumbai. Cities, 25(2), 73-85. doi.org/10.1016/j.cities.2008.01.003

Pan, H., Shen, Q., \& Zhang, M. (2009). Influence of urban form on travel behavior in four neighborhoods of Shanghai. Urban Studies, 46(2), 275-294. doi.org/10.1177/0042098008099355

Prefeitura de São Paulo. (2015). City of São Paulo strategic master plan. Retrieved from http://gestaourbana.prefeitura.sp.gov.br

OpenStreetMap. (2017). Planet dump. Retrieved from https://planet.osm.org, https://www.openstreetmap.org

Open TripPlanner. (2018). Retrieved from http://www.opentripplanner.org/

R Core Team. (2014). R: A language and environment for statistical computing. Vienna: R Foundation for Statistical Computing. Retrieved from http://www.R-project.org/

Robinson, J. (2011). Cities in a world of cities: The comparative gesture. International Journal of Urban and Regional Research, 35(1), 1-23. doi.org/10.1111/j.1468-2427.2010.00982.x

Rode, P., Kandt, J., \& Baker, K. (2016). Access to the city: Transport, urban form and social exclusion in São Paulo, Mumbai and Istanbul. (Working paper). London: LSE Cities, London School of Economics and Political Science.

Rolnik, R., \& Klintowitz, D. (2011). (Im)Mobility in the city of São Paulo. Estudios Avançados, 25(71), 89-108.

Salon, D., \& Aligula, E. M. (2012). Urban travel in Nairobi, Kenya: Analysis, insights, and opportunities. Journal of Transport Geography, 22, 65-76. doi.org/10.1016/j.jtrangeo.2011.11.019

Scheiner, J. (2014). Residential self-selection in travel behavior: Towards an integration into mobility biographies. Journal of Transport and Land Use, 7(3), 15-28. doi.org/10.5198/jtlu.v7i3.439

Schwanen, T. (2016). Geographies of transport II: Reconciling the general and the particular. Progress in Human Geography, 41(3), 355-364. doi.org/10.1177/0309132516628259

Shirgaokar, M. (2016). Expanding cities and vehicle use in India: Differing impacts of built environment factors on scooter and car use in Mumbai. Urban Studies, 53(15), 3296-3316. doi. org/10.1177/0042098015608050

Shirgaokar, M. (2014). Employment centers and travel behavior: Exploring the work commute of Mumbai's rapidly motorizing middle class. Journal of Transport Geography, 41, 249-258. doi. org/10.1016/j.jtrangeo.2014.10.003

Sudhakara Reddy, B., \& Balachandra, P. (2012). Urban mobility: A comparative analysis of megacities of India. Transport Policy, 21, 152-164. doi.org/10.1016/j.tranpol.2012.02.002

Tarigan, A. K. M., Susilo, Y. O., \& Joewono, T. B. (2014). Segmentation of paratransit users based on service quality and travel behavior in Bandung, Indonesia. Transportation Planning and Technology, 37(2), 200-218. doi.org/10.1080/03081060.2013.870792

Tekeli, I. (2009). Cities in modern Turkey. In R. Burdett (Ed.), Istanbul. City of intersections (pp. 16-17). London: Urban Age Program, London School of Economics and Political Science.

Terzi, F., \& Bölen, F. (2012). The potential effects of spatial strategies on urban sprawl in Istanbul. Urban Studies, 49(6), 1229-1250. doi.org/10.1177/0042098011410334 
Tiwari, G. (2007). Urban transport in Indian cities. In R. Burdett (Ed.), Urban India: Understanding the maximum city (pp. 39-40). London: Urban Age Program, London School of Economics and Political Science.

Tran, H. A., \& Schlyter, A. (2010). Gender and class in urban transport: The cases of Xian and Hanoi. Environment and Urbanization, 22(1), 139-155. doi.org/10.1177/0956247810363526

Venables, W. N., \& Ripley, B. D. (2002). Modern applied statistics with S. Fourth edition. New York: Springer.

Zegras, C. (2010). The built environment and motor vehicle ownership and use: Evidence from Santiago de Chile. Urban Studies, 47(8), 1793-1817. doi.org/10.1177/0042098009356125

Zhang, M. (2004). The role of land use in travel mode choice: Evidence from Boston and Hong Kong. Journalof the American PlanningAssociation, 70(3), 344-360. doi.org/10.1080/01944360408976383

Zhang, Y., Wu, W., Li, Y., Liu, Q., \& Li, C. (2014). Does the built environment make a difference? An investigation of household vehicle use in Zhongshan Metropolitan Area, China. Sustainability (Switzerland), 6(8), 4910-4930. doi.org/10.3390/su6084910 